\title{
Distribution and Host Range of the Burrowing Nematode in Puerto Rican Soils
}

\author{
Alejandro Ayala and Jessé Román ${ }^{1}$
}

\section{INTRODUCTION}

The burrowing nematode, Radopholus similis (Cobb, 1893) Thorne, 1949, was originally described from the Fiji Islands where it was found associated with a root disease of banana, Musa sapientum Kuntze (4) ${ }^{2}$. Cobb also $(\bar{b})$ in 1915 reported its presence in Hawaii, attacking sugarcane roots, Saccharum officinarum L. This same year Ashby (2) reported it from Jamaica. In these reports different scientific names were given to the same nematode but these were synonymized by Cobb under the name Tylenchus similis (5).

Zimmermann described Tylenchus acutocaudatus from coffee in Java, but Goodey (6) in 1932 synonymized it with Anguillulina similis. In 1949 Thorne (9) created the genus Radopholus for which the burrowing nematode was designated as type species.

This endoparasitic migratory nematode which feeds on cortical tissue and is able to reproduce generations inside of root tissue is considered the cause of several agricultural problems. Van der Vecht (11), after several experiments, concluded that it is the cause of the yellow disease of black pepper, Piper nigrum L. which occurs on the Island of Bangka in Indonesia. In 1953 Suit and Ducharme (10) demonstrated that the burrowing nematode is the causal agent of the spreading decline disease of citrus in Florida. It has been considered a major problem in banana production in Panama (7) and Jamaica (8). It has been also regarded a limiting factor in ornamental production in various countries.

In 1955 a quarantine was established in California for preventing the introduction of this parasitic nematode from Puerto Rico, Florida, and Hawaii in ornamental material. For this reason a study was undertaken here with the purpose of determining the extent of occurrence of this nematode in the Island. In this study samples were obtained from six of the

1 Assistant Nematologists, Agricultural Experiment Station, University of Puerto Rico, Río Piedras, P.R. The authors wish to express their gratitude to Miss C. T. Ramirez of the Nematology Section, who cooperated in this study; to Dr. L. F. Martorell, Head of the Department of Entomology, under whose recommendation this study was initiated; to the Nematology Laboratories of the Department of Agriculture in Beltsville, Md., which, through Miss Edna Buhrer, cooperated in the verification of identifications; and to Dr. A. C. Tarjan, Citrus Experiment Station, Lake Alfred, Fla., who kindly made corrections and suggestions.

2 Italic numbers in parentheses refer to Literature Cited, pp. 36-7. 
largest ornamental-producing nurseries. Additional samples were taken from other plants including plantain, banana, sugarcane, pineapple, citrus, coffee, and some other minor crops.

\section{MATERIALS AND METHODS}

The study was divided into two main parts, one including ornamentals, and the second other plant species which had been reported as hosts of this nematode.

For the first part, six nurseries, located at Arecibo, Toa Alta, Vega Alta, Río Piedras, Cataño, and Río Grande, and all exporting plant ornamental material to the United States, were sampled. Several soil and root samples were taken from different plant species. Soil samples consisted of 100 to $600 \mathrm{cc}$. of soil from the rhizosphere, while root samples were up to $50 \mathrm{gm}$. in weight. Most of the nematodes observed were identified by the authors; others were sent to the USDA Nematology Laboratories in Beltsville, Md., for verification, especially during the first year of the study.

The second part consisted of the study of samples from several other plant species of economic importance growing in different localities in Puerto Rico. Most of the samples were taken from plants which were known hosts of this nematode species, some of which showed symptoms of possible infestation, while others did not. The same amount of roots and soil as for the first part was processed.

The screen and Baermann-funnel methods were used for recovering nematodes from the soil and the same methods, and the Waring Blendor, for those found in the roots. Determinations of nematode species were made under high magnification. Direct observations were made of roots so as to determine the presence of the parasites and the type of damage caused by them.

\section{RESULTS AND OBSERVATIONS}

\section{ORNAMENTALS}

Several nematode genera were found affecting ornamental roots, among which were Meloidogyne incognita, Helicotylenchus nannus, Rotylenchulus reniformis, Pratylenchus spp., Tylenchus spp., and Trichodorus spp., in decreasing order of occurrence. The burrowing nematode was found only in three of the six nurseries surveyed (Rio Piedras, Toa Alta, and Arecibo). In two of these nurseries the burrowing nematode populations were small, while in the third (Arecibo) the nematode was evenly distributed among ornamentals and banana plants growing together.

Only 8 plant species of the 25 included in the study were found to be affected by the parasite; all but one belonged to the Araceae. In Arecibo, where the nematode was widely distributed and numerous, the plants 
were chlorotic, stunted, and of very poor quality for exportation. The roots were short and necrotic with very few side roots, providing very little support for the plants.

The following tabulation shows the results of this study:

Plant Species

Anthurium acaule (Jacq.) Schott

Heliconia aurantiaca Ghieslv.

Philodendron cordatum Hort. ( $=$ P. oxycordium Schott)

$P$. dubium Hort. (= P. radiatum Schott)

$P$. hastatum Hort.1

$P$. mandaianum (hastatum + erubescens) (hybrid)

$P$. pertusum Kunth \& Bché

Pothos aureus Lindl. \& Audré

(= Scindapsus aureus (Lindl. \& André Engl.)
Locality

Arecibo

Do.

Toa Alta

Do.

Arecibo, Río Piedras

Arecibo

Do.

Do.

\section{Botanical status undetermined}

\section{OTHER NONORNAMENTAL CROPS}

Although more than $\mathbf{5 0 0}$ root and soil samples were processed, including more than 100 species of plants, the burrowing nematode was found in the roots of only 4. Its most important hosts were plantain, Musa paradisiaca L., and banana, Musa sapientum L. It was also found in noncultivated cotton, Gossypium hirsutum L. var. punctatum Hutchins, Silow \& Stevens, and coffee, Coffea arabica L. var. Puerto Rico. All other crops were found free of this parasitic nematode.

\section{Distribution}

The distribution of the burrowing nematode was almost confined to plantain and banana plantations. Sixty samples were taken from fields devoted to the production of these two crops in the northern and central parts of the Island. Ninety percent of these were found infected. This wide distribution was probably due to the use of infected propagating material or "seed".

The nematodes were carried in roots and soil particles and, even when the "seed" corms were trimmed or cleaned, nematodes were carried to clean areas when this was not properly done (fig. 1). Some of these fields were eventually abandoned to weeds and pasture, but the plantain and banana plants were not destroyed completely, and the roots served as reservoirs of the parasite.

Infestations were detected in all types of soils from the sandy dry loams found at sea level to the moist heavy clays of the mountains. The heaviest populations were found in the latter type. The burrowing nematode was first located in a heavy clay of a plantain site in the Corozal Substation. 
Subsequent findings were made in Trujillo Alto, Utuado, Naranjito, and Cupey Alto where steep land and heavy soils prevailed, and in Arecibo, Rio Piedras, and Isabela, where the land is flat and soils are of lighter texture. In none of these locations were the roots of other plants of economic importance, or of weeds growing near plantain or banana plants, found infected with this particular parasite.

The nematode was recovered also from coffee roots of plants growing under shade, at about 2,500 feet above sea level, near Jayuya. Plantain and citrus roots intermingled with coffee roots were free of the parasite.

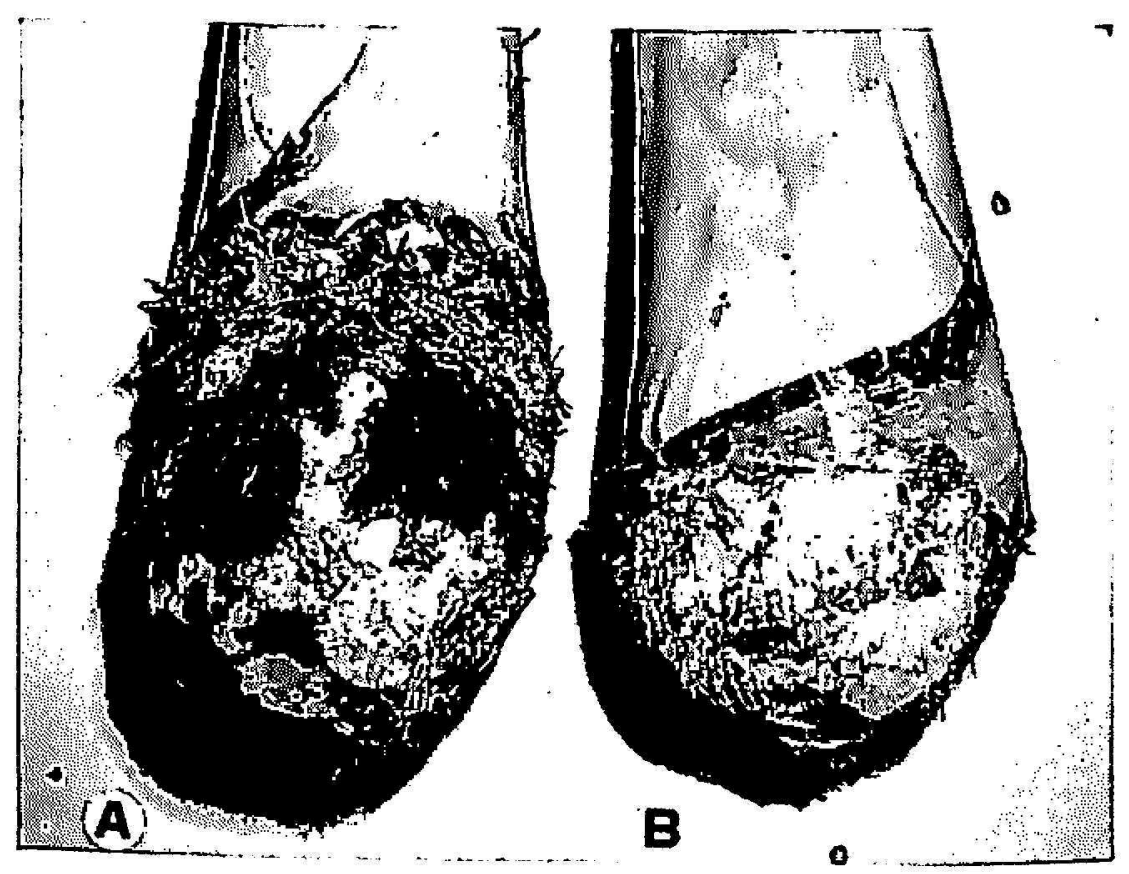

Fic. 1.-Two "seed" of plantain which have been trimmed to eliminate roots: A, Improperly trimmed corm showing necrotic areas where Radopholus similis and saprophagous nematodes are numerous; B, well-trimmed "seed" free of the nema-
tode.

Noncultivated cotton growing in a sandy soil near a riverbank and also near a sugarcane plantation was found infected; however, the roots of the cane were found free of infection.

\section{Symptoms and Damage Observed}

Burrowing nematode attack was easily recognized in banana and plantain fields. Plants were usually chlorotic, stunted, with thin pseudostems and short curled leaves (fig. 2), and produced very small bunches of fruits. Infections were usually found in spots or in patches but very often the whole plantation showed symptoms. The root systems of these plants were reduced and necrotic.

Recent invasions of roots were noticeable as small brown or black spots, 
but in older roots with severe infestations these necrotic areas were quite extensive (fig. 3). The burrowing nematodes entered the roots by puncturing epidermal cells and feeding on cortical tissue. As the attacked cells were destroyed the nematodes migrated through the roots in search of new feeding sites, thus extending the lesions. As a result the distal parts of the roots usually died, death being hastened by the invasion of other organisms such as bacteria and fungi. New roots were formed accordingly, but these in turn were readily attacked. The result was a group of shortened blackish

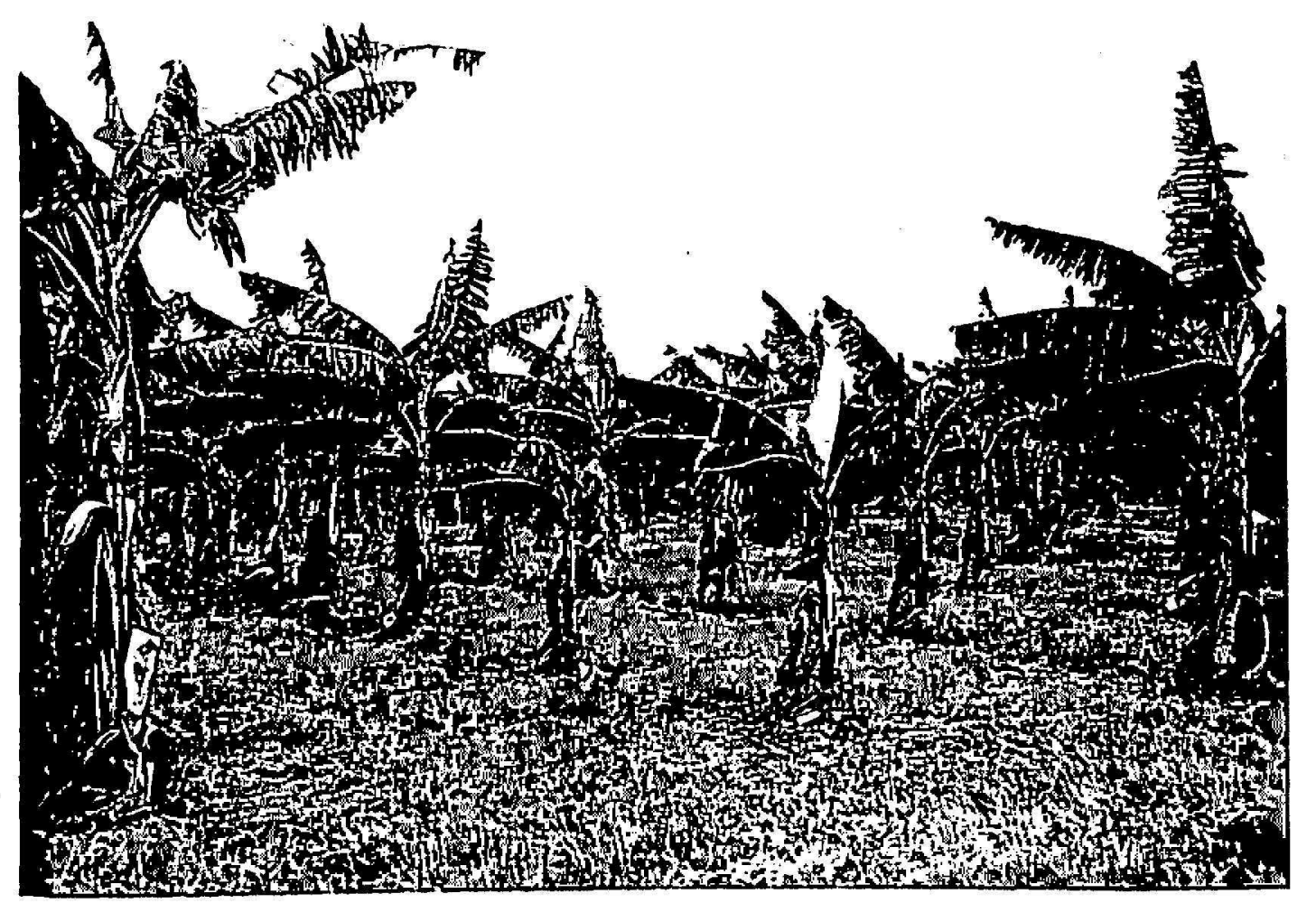

Fig. 2.-Diseased plantain field in which most of the plants show nematode-attack symptoms. Small plants with thin pseudostems, curled and small leaves, and abnormal root systems, produce only small bunches of fruits.

roots (fig. 4) that gave very little structural support to the plant which tipped over easily, especially with the weight of the fruit or the effect of even light winds.

In fleshy roots different areas of coloration were observed associated with the infection. At the point of the original invasion roots were black, then brown, then purple, and finally reddish or yellow at edges of the discoloration. These symptoms were observed also in the corms of old and new plants as shown in figure 1.

Very often, mixed populations of the burrowing nematode and Rotylenchulus reniformis, Meloidogyne spp., Helicotylenchus nannus, and H. multi- 
cinctus were predominant, but the first species usually predominated. In some fields the spiral nematode was more abundant, but the symptoms were not pronounced. In cotton and coffee no specific symptoms could be associated with infection of the burrowing nematode. It was found associated with root knot, Meloidogyne incognita and root-lesion nematodes,

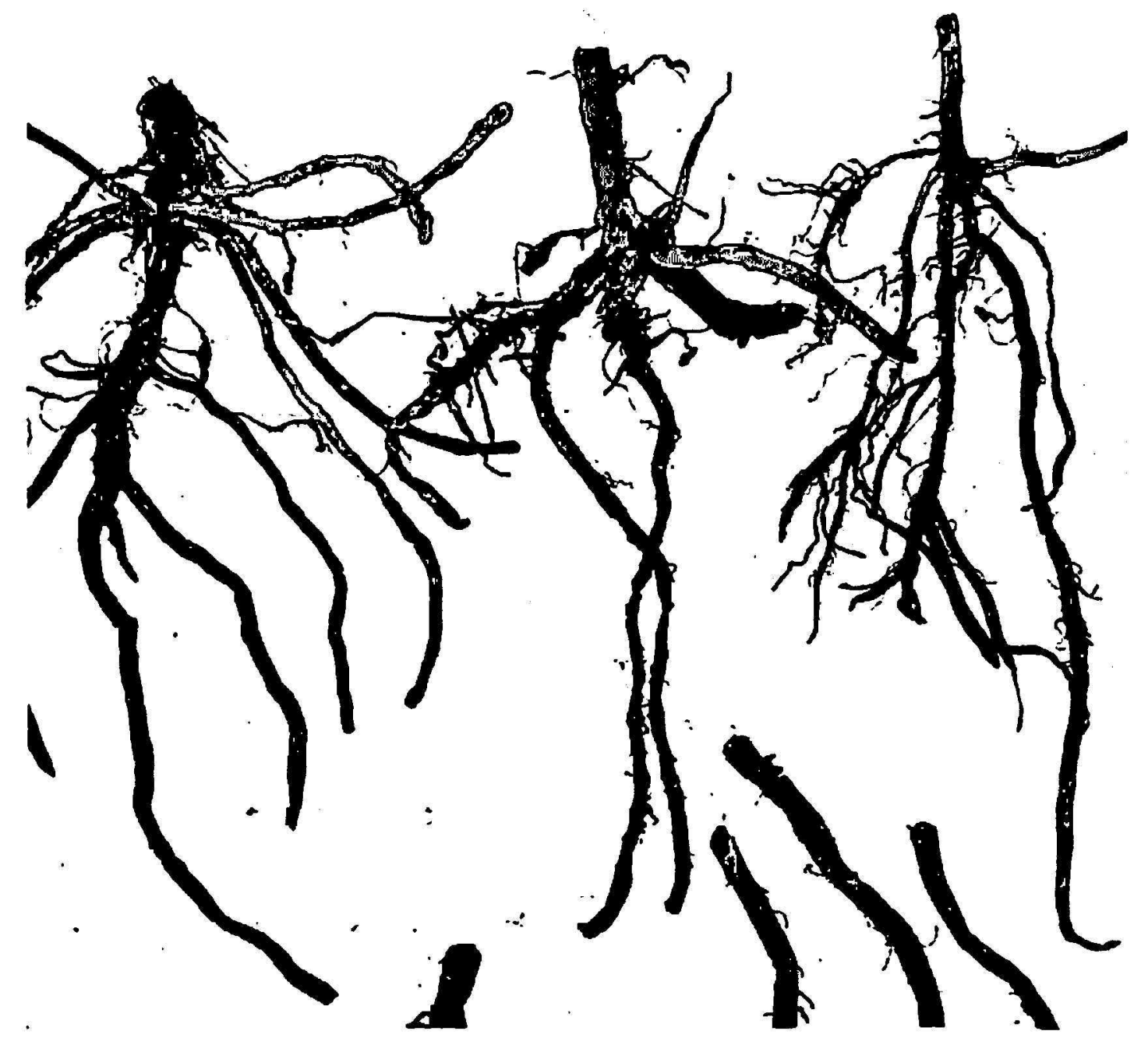

FIc. 3.-Typical roots from plantains heavily infested with the burrowing nematode; intense proliferation of the roots and necrosis may be observed.

Pratylenchus coffeae, in one very poorly growing area of shaded coffee. In cotton, Tylenchorhynchus sp. and Rotylenchulus reniformis were also numerous, but symptoms were not associated with a specific type of nematode.

\section{DISCUSSIOX}

The burrowing nematode, Radopholus similis, was found distributed mostly along the northern coast and central part of P'uerto Rico, associated with ornamentals, plantain, and banana. It was not widespread in ornamentals, being found only in three of six nurseries studied; eight species 
of the plants investigated were found affected by the parasite. Four other species of plants were also found infected. This makes a total of 12 host plants of this nematode in Puerto Rico. It is evident that its host range

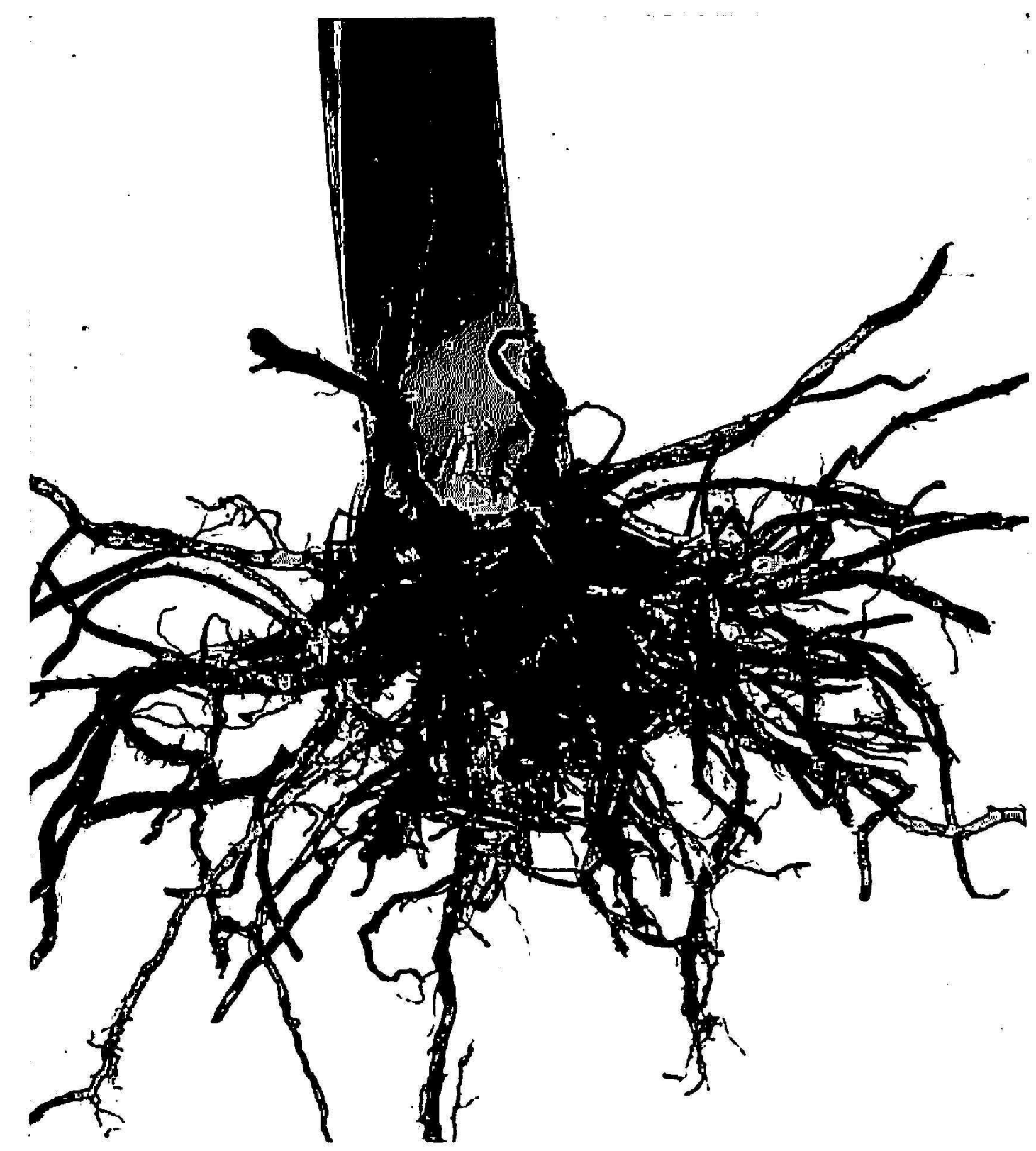

Fig. 4.-Abnormal plantain root system from a field heavily infested with the burrowing nematode. The primary roots may be seen cut; necrosis and proliferation of roots are marked. This root system does not give enough support to the plant which eventually tips over.

here is very limited compared to its host range in other countries. At least 125 plant species are reported by Christie (2) as being hosts or suspected hosts; 17 varieties, kinds, or hybrids of citrus are also included. Of these plant species at least 106 have been found attacked by the burrowing 
nematode in Florida. Sixteen new hosts were reported from Florida in 1959 (12). In a previous report (1) from Puerto Rico three different species already known as hosts were reported. Five of the species here reported are probably newly announced hosts: Anthurium acaule (Jacq.) Schott, Heliconia aurantiaca Ghieslr., Philodendron pertusum Kunth \& Bché, Pothos aureus Lindl. \& André, and Gossypium hirsutum L. var. punctatum Hutchins, Silow, \& Stevens.

The best hosts seemed to be plantain and banana, and it was apparent that the form involved is of the "banana" race which did not infect citrus and sugarcane. The form infecting coffee was probably a different race, since it did not transfer to banana growing in the same location. It has also been reported that several species of burrowing nematodes are present in the Island (1).

The burrowing nematode has been recognized as the cause of root rot in banana and plantain especially in Panama, Jamaica, and Ghana (Africa). In Puerto Rico it has not yet been associated with the incidence of Fusarium sp. and Rhizoctonia sp.

Wherever the nematode has been found affecting banana and plantain, whole plantations have been destroyed and, in most cases, the effect of the parasite is more noticeable after the first crop is produced, at which time the plants will usually tip over and the young shoots will appear sick.

It appears that the burrowing nematode was introduced into Puerto Rico with infected plantain or banana propagating material. It has been introduced into new fields the same way and from banana to ornamentals by planting these in fields previously used for bananas and plantain or growing them together.

\section{SUMMARY}

Because of quarantine recently established by the State of California on ornamental material imported from Puerto Rico, Hawaii, and Florida, a study was undertaken in 1955 , which lasted until 1960, to determine the distribution of the burrowing nematode in Puerto Rico. Six of the most important ornamental nurseries and several localities in which economic important crops are grown were sampled.

Eight different ornamental plants were found infected with burrowing nematodes in three of the nurseries. The nematode was found to be widely distributed and a serious problem in one of the nurseries, where it was presumably introduced with infected banana material. In the other two the nematode was present in limited numbers only and infected very few plants.

The nematode was well distributed in banana and plantain, in which it caused a root rot condition that usually destroyed whole plantations. The distribution of the nematode and symptoms caused to these crops are 
discussed. Coffee and noncultivated cotton were also found to be attacked by the nematode. Five of the twelve plant species here reported as hosts of the burrowing nematode in Puerto Rico are probably newly reported hosts.

\section{RESUMEN}

En el 1955 se inició un estudio para determinar la distribución del nemátodo barrenador, Radopholus similis en ornamentales y otras plantas en la Isla. Este estudio se inició debido a una cuarentena impuesta por el estado de California al material de ornamentales importado de Puerto Rico, Hawaii y Florida. Se estudiaron muestras de suelo y raíces de seis de los viveros más importantes y de muchas otras áreas donde se cultivan cosechas de importancia económica.

Se encontraron ocho especies de ornamentales que son susceptibles al ataque de este nemátodo en tres viveros diferentes. El nemátodo barrenador es un serio problema en uno de los viveros (Arecibo), donde se encontró bien distribuido en toda el área, tanto en ornamentales como en plátanos. Esta última planta seguramente sirvió como portadora del nemátodo cuando se introdujo en este área. En los otros dos viveros las poblaciones del parásito eran ínfimas y atacaban sólo a una o dos especies de plantas.

El nemátodo barrenador se encontró en casi todas las plantaciones de plátano y guineo que se incluyeron en el estudio, causando podredumbre de la ráíz y de la macolla, y la eventual destrucción de toda la plantación. En este trabajo se discute la distribución del mencionado organismo y los síntomas observados. El café y el algodón silvestre también son atacados por este nemátodo, aunque el daño no es mucho. Se informan 12 plantas hospedadoras, 5 de las cuales probablemente no han sido informadas por otros investigadores.

\section{LITERATURE CITED}

1. Anon., Distribution of plant parasitic nematodes in the South, Southern Co-op* Series Bul. 74 pp. 9-72, 1960.

2. Birchfield, W., The burrowing nema situation in Florida, J. Econ. Ento. 60 (5) $562-4,1957$.

3. Christie, F. R., Plant Nematodes: Their Bionomics and Control, H. \& W. B. Dreu Co., Jacksonville, Fla., pp. 96-113, 1959.

4. Cobb, N. A., Nematodes mostly Australian and Fijian Macleay Memorial Vol. Linn. Soc. N. South Wales, pp. 253-308, 1893.

5. - Tylenchus similis, The cause of a root disease of sugarcane and banana, $J$. Agr. Res. 4 (6) 561, 1915.

6. Goodey, T., The Genus Anguillulina Gerv. and N. Ben., 1859, vel Tylenchus Bastian, 1805, J. Heminth. 10 75-180, 1932.

7. Loos, C. A., Symptom expression of Fusarium wilt disease of the Gros Michel banana in the presence of Radopholus similis (Cobb, 1893) Thorne 1949 and 
Meloidogyne incognita acrita Chitwood 1949, Proc. Helminth. Soc. Wash. 26 (2) 103-11, 1959.

8. - Eradication of the burrowing nematode, Radopholus similis, from bananas, Plant Dis. Rptr. 46 (6) 457-61, 1961.

9. Thorne, G., On the classification of Tylenchidae, New Order (Nematoda, Phasmidia), Proc. Helminth. Soc. Wash. 16 (2) 37-73, 1949.

10. Suit, R. F., and Ducharme, E. P., The burrowing nematode and other plant parasitic nematodes in relation to spreading decline of citrus, Plant Dis. Rptr. 37 (7) 379-83, 1953.

11. Vecht, J. van der, Op planten parasiterende aaltjes (Tylenchidae), Plagen van de cultuurgewassen in Indonisië, pp. 16-42, 1950.

12. Van Weerdt, L. G., Birchfield, W., and Esser, R. P., Observations on some Subtropical Plant Parasitic Nematodes in Florida, Soil and Crop Sci. Soc. Fla. Proc. 19 443-51, 1959. 